\title{
Analisis Yuridis Arena Kajian Antropologi Hukum di Tingkat Perguruan \\ Tinggi
}

\author{
Nama Mahasiswa : Robert Haryanto \\ Email: robertharyanto23@gmail.com
}

No BP:2110003600252

Universitas Eka Sakti

\section{A. PENDAhUluan}

Antropologi secara etimologis berasal dari bahasa Yunani. Kata Anthropos berarti manusia dan logos berarti ilmu pengetahuan. Jadi antropologi adalah ilmu yang mempelajari manusia. Dalam ilmu antropologi hukum dipelajari mengenai peran, status atau kedudukan,nilai, norma juga kebudayaan. Semua ini sangat erat kaitannya dengan ilmu antropologi hukum. Sebelum berdirinya Komunisme, magistrat-magistrat Tiongkok, misalnya, tidak berurusan dengan menginterpretasi dan menerapkan aturan hukum untuk kasus-kasus konflik yang terjadi, namun menggunakan aturan hukum hanya sebagai pedoman teladan-teladan yang sangat berguna, tetapi tidak harus diteladani dalam kasus konkrit. Dalam antropologi hukum tidak dapat membatasi diri pada isi peraturan-peraturan hukum dan bentuk-bentuks anksinya, tapi yang perlu diketahui dengan jelas adalah proses pembentukan hukumnya.Antropologi hukum adalah ilmu yang mempelajari tentang manusia dan budayanya khusus dibidang hukum. Kebudayaan hukum yang dimaksud adalah kekuasaan yang digunakan oleh penguasa untuk mengatur masyarakat agar tidak melanggar kaidah-kaidah sosial yang telah ada didalam suatu masyarakat itu sendiri.Hukum dipahami sebagai milik sebuah masyarakat sebagai suatu keseluruhan.Konsekuensi logisnya, suatu masyarakat dianggap hanya memiliki satu sistem hukum saja yang mengendalikan perilaku semua anggotanya. Tanpa sedikit pun 
menyelidiki kontrol-kontrol sosial yang bekerja pada tingkat submasyarakat, subkelompok (misalnya,perkumpulan, kelompok orang yang hidup serumah, dan kelompok kerabat) telah secara apriori dikecualikan dari kemungkinan mengatur perilaku anggotanya dengan sistem yan gditerapkan oleh pemimpin kelompok dalam keputusan-keputusan khusus sistem yang berdasarkan ciri-ciri khas esensinya amat sangat menyerupai hukum pada masyarakat yang meliputi semua kalangan.Hukum juga diartikan sebagai disiplin (sistem ajaran tentang kenyataan) dan ilmu pengetahuan (yakni ilmu hukum). Sebagai ilmu pengetahuan, maka hukum dikatakan mencangkup ilmu tentang kaidah, ilmu tentang pengertian dasar sistem hukum dan ilmu kenyataan (seperti misalnya sosiologi hukum, antropologi hukum,psikologi hukum,perbandingan hukum dan sejarah hukum) Pengertian lain tentang hukum yaitu bahwa hukum diartikan sebagai proses pemerintahan. Proses pemerintahan itu mencangku peraturan, pemerintahan dalam artisempit, penanggulangan serta peradilan. Hukum diartikan pula sebagai jalinan nilai. Nilai tersebut merupakan konsepsi abstrak di dalam diri manusia mengenai apa yang dianggap baik serta apa yang dianggap buruk. Hukum diartikan sebagai nilai yang merupakan salah satu unsur pandangan manusia mengenai hal-hal yang seharusnya dianuti karena dianggap baik,dan hal-hal yang seharusnya dihindari karena dianggap buruk. Saya memilih mengangkat masalah ini menjadi judul makalah saya karena antropologi hukum adalah salah satu mata kuliah yang saya pelajari pada jurusan yang saya pilih dan juga antropologi hukum di tingkat perguruan tinggi ini adalah pembelajaran mengenai perilaku manusia dari segala aspek . Pembahasan materi ini juga berguna untuk menambah wawasan saya terhadap materi yang saya pilih . 


\section{B. PEMBAHASAN}

\section{PENGERTIAN ANTROPOLOGI HUKUM}

Antropologi berasal dari bahasa Yunani, Antropos yang artinya manusia dan Logos yang artinya ilmu. Ilmu tentang hayati terdiri dari:

1. Paleo Antropologi, yaitu mempelajari tentang asal usul manusia dan perkembangannya. Metode yang digunakan dengan penggalian fosil-fosil. Bagian yang dipelajari adalah organorgan dalam tubuh.

2. Antropologi Fisik, yaitu mempelajari bentuk-bentuk manusia, baik bagian dalam maupun bagian luar tubuh. Tujuannya mempelajari corak ragam manusia.

Jadi, Antropologi Hukum adalah kajian antropologi terhadap makna sosial dari dan pentingnya hukum dengan menelaah bagaimana hukum dibuat termasuk bagaimana konteks sosial pembuatan hukum tersebut, bagaimana hukum mempertahankan dan mengubah institusi sosial lainnya, dan bagaimana hukum membangun perilaku sosial.

\section{PEMBAGIAN ANTROPOLOGI}

Antropologi mempelajari perkembangan kehidupan manusia dan budayanya, dengan

cabang-cabang ilmu, diantaranya; ilmu PraSejarah untuk mempelajari kehidupan asal usul manusia, dan untuk mengetahui ragam bahasa manusia maka harus mempelajari Etnolinguistik, sedangkan ilmu yang mempelajari cara manusia berbangsa dan berbudaya disebut Etnologi. 
Antropologi adalah studi ilmu yang mempelajari tentang manusia dari Aspek Budaya, Perilaku, Nilai, Keanekaragaman, dan lainnya. Antropologi terbagi dalam: Antropologi

Ekonomi, Antropologi Politik, Antropologi Pendidikan, dan Antropologi Hukum.

Antropologi Hukum merupakan ilmu yang mempelajari manusia dengan kebudayaan, khususnya di bidang Hukum, atau ilmu tentang Manusia dalam kaitannya dengan Kaidahkaidah sosial yang bersifat Hukum.

\section{BUDAYA DAN KEBUDAYAAN HUKUM}

Kebudayaan hukum adalah kekuasaan yang digunakan oleh penguasa untuk mengatur masyarakat agar tidak melanggar kaidah-kaidah sosial yang telah ada dalam masyarakat. Hukum diperlukan meski telah ada kaidah atau norma dalam masyarakat, agar terdapat keteraturan dalam kehidupan manusia melalui hukum tertulis dengan sanksi yang nyata disamping norma dan kaidah yang sanksinya lebih bersifat sosial atau akhirat.

Sebagai Ilmu Pengetahuan, Antropologi Hukum dicirikan oleh 3 (tiga) hal yaitu adanya: Objek, Metode, dan Sistem. Antropologi Hukum sebagai ilmu pengetahuan yang merupakan spesialisasi dari Antropologi Budaya, memiliki karakter:

1. Antropologi Hukum, adalah Ilmu pengetahuan (logos) tentang Manusia (antropos) yg berhubungan dengan Hukum;

2. Manusia, adalah manusia yg hidup bermasyrakat, masyarakat yg masih sederhana budayanya (primitif) dan yg sudah Maju (modern);

3. Budaya adalah Budaya Hukum, yaitu segala bentuk perilaku budaya manusia yg mempengaruhi Masalah Hukum. Budaya adalah milik bersama yang perlu dipertahankan atau dilestarikan. 
Budaya hukum adalah tanggapan masyarakat terhadap suatu perbuatan yang dianggap baik, yang hal ini juga bergantung pada sikap penegak hukum. Nilai budaya atau Postulat adalah nilai yang ada dalam masyarakat modern dan masyarakat sederhana yang dinilai baik atau dipertahankan. Masalah Hukum tidaklah hanya pada masalah hukum yang normatif (undangundang), atau masalah hukum yang merupakan pola perilaku yg sering terjadi (hukum adat ), tetapi juga masalah budaya terhadap suatu masalah Hukum, dikarenakan adanya Faktor Budaya yang mempengaruhinya, yaitu:

1.Faktor-faktor Budaya yg melatar belakangi Masalah Hukum

Contoh: cara menyelesaikan masalah perselisihan dikalangan Orang Batak, tidak sama dengan orang Minang, Jawa, Bali, Maluku dan lainya;

2. Cara-cara tersebut menjadi objek perhatian Antropologi Hukum.

\section{ARENA KAJIAN ANTROPOLOGI HUKUM}

Kajian Antropologi Hukum adalah menggali norma dan nilai-nilai dalam masyarakat.Arena Antropologi Hukum mempelajari manusia dan budaya hukum, karenanya kaidah sosial yang tidak bersifat hukum bukanlah sasaran pokok penelitian Antropologi Hukum.

Norma/kaidah menurut Antropologi Hukum pola ulangan perilaku dalam masyarakat. Norma/Kaidah adalah nilai dasar yang ada dalam masyarakat yang dapat mengukur perilaku manusia agar dapat menilai mana perbuatan benar dan mana yang tidak benar. Norma memiliki aspek hukum ketika aparat menjatuhkan sanksi karena ada perbuatan yang menyimpang atau melanggar hukum. Sanksi bersifat positif seperti dengan membayar denda atau kerja sosial, dan sanksi bersifat negatif seperti hukuman badan atau dikucilkan. Hukum muncul dari peradaban manusia, dimana ada 2 orang atau lebih di situ ada hukum. 


\section{SIFAT KEILMUAN ANTROPOLOGI HUKUM}

1. Antropologi Hukum tidak membatasi pandangan pada kebudayaan tertentu (studi

perbandingan).

2. Antroplogi Hukum, mempelajari masyarakat sebagai suatu keseluruhan yang utuh,

dimana bagian-bagiannya saling bertautan.

3. Antropologi Hukum Modern tidak memusatkan perhatian hanya pada kekuatan sosial

dan hal superorganis.

4. Antropologi Hukum memandang masyarakat secara Dinamis, sehingga peranan sosial dan Hukum tidak terbatas mempertahankan status quo.

5. Antropologi Hukum termasuk ilmu Hukum yang empiris.

\section{HUBUNGAN ANTROPOLOGI HUKUM DENGAN ILMU SOSIAL LAINNYA}

Hubungan antropologi hukum dengan ilmu sosial lainnya sebagai berikut: 1. Antropologi

Hukum dengan Hukum Adat;

2. Antropologi Hukum dengan Sosiologi;

3. Antropologi Hukum dengan Etnologi;

4. Antropologi Hukum dengan Religi;

5. Antropologi Hukum dengan Psikologi Sosial. 


\section{CARA MEMPELAJARI ANTROPOLOGI HUKUM}

1. Metode Historis, yaitu mempelajari perilaku manusia melalui sejarah kebiasaan yang ada dalam masyarakat menjadi adat, berkembang menjadi hukum adat, yang dipertahankan oleh penguasa lalu menjelma sebagai hukum negara.

2. Metode Normatif Eksploratif, yaitu mempelajari perilaku manusia dan budaya hukumnya melalui norma hukum yang sudah ada / yang dikehendaki, bukan sebatas norma hukum yang berlaku, melainkan melihat perilaku manusia barulah mengetahui hukum yang akan diterapkan.

3. Metode Deskriptif Perilaku, yaitu mempelajari perilaku manusia dan budaya hukumnya melalui hukum yang nyata tanpa melihat aturan hukum ideal. Metode ini sempurna apabila disertai metode kasus.

4. Metode Studi Kasus, yaitu pendekatan Antropologi Hukum dengan mempelajari kasuskasus yang terjadi terutama kasus perselisihan. 


\section{PENUTUP}

Antropologi adalah ilmu yang mempelajari manusia. Oleh karena itu antropologi didasarkan pada kemajuan yang telah dicapai ilmu pengetahuan sebelumnya. Pengertian Antropologi dapat dilihat dari 2 sisi yaitu Antropologi sebagai ilmu pengetahuan artinya bahwa Antropologi merupakan kumpulan pengetahuan-pengetahuan tentang kajian masyarakat dan kebudayaan yang disusun secara sistematis Antropologi yang kedua adalah cara-cara budaya yang ada dalam masyarakat dipertanggungjawabkan kebenarannya secara ilmiah. atas dasar pemikiran yang logis dan pengertian berpikir untuk mengungkapkan realitas sosial dan dengan prosedur dan teori yang dapat

Setelah di kaji kita dapat mengemukakan hasilnya bahwa manfaat di dalam antropologi hukum sangat luas. Antropologi hukum telah memberikan kontribusi yang sangat besar terhadap perkembangan ilmu hukum. Kesimpulan yang dapat diambil adalah dimana pun kita berada, kita tidak akan pernah jauh dari hukum selama kita berada di Negara hukum. Antropologi hukum juga sangat memiliki keterkaitan terhadap banyak hal apalagi pada ruang lingkup pendidikan perguruan tinggi , pelajaran Antropologi sangat penting untuk dipahami agar mahasiswa dan pengajar dapat memiliki wawasan dalam terhadap antropologi hukum 


\section{DAFTAR PUSTAKA}

Darmini Roza dan Laurensius Arliman S, Peran Pemerintah Daerah Di Dalam Melindungi Hak Anak Di Indonesia,Masalah-

Masalah Hukum, Volume 47, Nomor 1, 2018.https://doi.org/10.14710/mmh.4 7.1.2018.10-21

Laurensius Arliman S, Peranan Metodologi Penelitian Hukum di Dalam Perkembangan

Ilmu Hukum di Indonesia,Soumatera Law Review, Volume 1, Nomor 1, 201. http://doi.org/10.22216/soumlaw.v1i1.3346.

Laurensius Arliman S, Peran Badan Permusyawaratan Desa di Dalam Pembangunan Desa dan Pengawasan Keuangan Desa, Padjadjaran Journal of Law, Volume 4, Nomor 3, 2017. https://doi.org/10.15408/jch.v4i2.3433.

Laurensius Arliman S, Penanaman Modal Asing Di Sumatera Barat Berdasarkan Undang- Undang Nomor 25 Tahun 2007 Tentang Penanaman Modal, Supremasi Hukum, Volume 1,Nomor 1, 2018.http://dx.doi.org/10.36441/hukum.v1i01.102 .

Laurensius Arliman S, Memperkuat Kearifan Lokal UntukMenangkal Intoleransi

Umat Beragama Di Indonesia,Ensiklopedia of Journal, Volume 1, Nomor 1, 2 018,https://doi.org/10.33559/eoj.v1i1.18.

Laurensius Arliman S, Perkawinan Antar Negara Di Indonesia Berdasarkan Hukum Perdata Internasional, Kertha Patrika,Volume 39, Nomor 3, 2017, https://doi.o rg/10.24843/KP.2017.v39.i03.p03.

Laurensius Arliman S, Partisipasi Masyarakat Di DalamPengelolaan Uang Desa Pa sca Undang-Undang Nomor 6 Tahun 2014 Tentang Desa, Jurnal Arena Hukum, Volume 12, Nomor

2019,https://doi.org/10.21776/ub.arenahukum.2019.01202.5.

Laurensius Arliman S, Mewujudkan Penegakan Hukum YangBaik Di Negara Huk um Indonesia, Dialogica Jurnalica,Volume 11, Nomor 1, 2019,https://doi.org/ 10.28932/di.v11i1.1831.

Laurensius Arliman S, Mediasi Melalui Pendekatan Mufakat Sebagai Lembaga Alternatif Penyelesaian Sengketa UntukMendukung Pembangunan Ekonomi Nasional, UIR LawReview, Volume 2, Nomor 2, 2018, https://doi.org/10.2529 9/uirlrev.2018.vol2(02).1587

Laurensius Arliman S, Peranan Filsafat Hukum DalamPerlindungan Hak Anak Ya ng Berkelanjutan SebagaiBagian Dari Hak Asasi Manusia, Doctrinal, Volume 1,Nomor 2, 2016.

Laurensius Arliman S, Ni

Putu

Eka

Dewi, Protection ofChildren and Women's Rights in Indonesia through

International Regulation Ratification, Journal of Innovation, Creativity and Change Volume 15, Nomor 6, 2021.

Laurensius Arliman S, Gagalnya Perlindungan Anak Sebagai Salah Satu Bagian Dari 
Hak Asasi Manusia Oleh OrangTua Ditinjau Dari Mazhab Utilitarianisme, Ju rnal Yuridis,Volume 3, Nomor 2, 2016,http://dx.doi.org/10.35586/.v3i2.180.

Laurensius Arliman S, Tantangan Pendidikan Kewarganegaraan Pada Revolusi 4.0, Jurnal Ensiklopedia Sosial Review,Volume 2, Nomor 3, 2020. 